http://www.jfas.info

\title{
WATER QUALITY ASSESSMENT OF THE RIVERS IN BAUXITE MINING AREA AT KUANTAN PAHANG
}

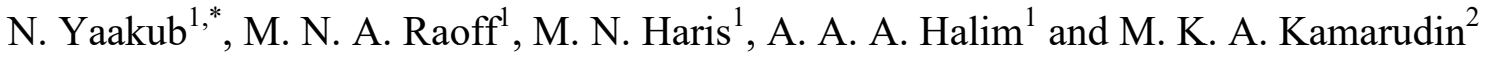 \\ ${ }^{1}$ Faculty of Bioresources and Food Industry, Universiti Sultan Zainal Abidin, 22200 Besut, \\ Terengganu, Malaysia \\ ${ }^{2}$ East Coast Environmental Reserach Institute, Universiti Sultan Zainal Abidin, Gong Badak \\ Campus, 21300 Kuala Terengganu, Terengganu, Malaysia
}

Published online: 08 August 2017

\begin{abstract}
This study was carried out to determine the water quality assessment in nearby rivers that in bauxite mining area. Water samples were collected at Kuantan River, Riau River, Pinang River and Pandan Rivers. In situ parameters used in this study were Temperature, pH, DO, TDS and BOD. Laboratory parameters analyzed in this study were TSS, Turbidity and COD. WQI was calculated using the formula from DOE 2012. Results showed that One-Way ANOVA test $(\mathrm{P}<0.05)$ for Temperature, DO, Ammonia-Nitrogen, BOD, TSS, Turbidity and COD had significantly different between the rivers while $\mathrm{pH}$ and TDS shows not significantly different between the rivers. WQI of Kuantan River, Pandan River, Riau River and Pinang River were $77.141,77.478,81.238$ and 83.164 respectively. All these rivers were classified into class II based on INWQS and required conventional treatment for water supply purposes.
\end{abstract} Keywords: bauxite; water quality index; water quality; Pahang.

Author Correspondence, e-mail: nadzifah@unisza.edu.my doi: http://dx.doi.org/10.4314/jfas.v9i2s.47 


\section{INTRODUCTION}

Bauxite mining in Kuantan offers some exciting economic opportunities for various parties including individual land owners. Nevertheless, the "bauxite boom"; the extensive and uncontrolled mining activities have great potentials to cause adverse impacts on the environment, health and quality of life of the people living in the affected areas. Bauxite mining is not a new economic activity for Malaysia. According to Minerals and Geoscience Department Malaysia 2010, the mining of bauxite has taken place in the state of Johor since early 2000. Whilst bauxite mining operation in Teluk Ramunia Johor has been operating for more than 15 years without much controversy, bauxite mining in Kuantan has created a different scenario within a short period of time. Extensive and aggressive mining which include transporting and stockpiling of bauxite in huge quantities cause environmental problems to emerge within a short period of time leading to community outrage [1]. Bauxite in Kuantan area is formed from basalt. Bukit Goh is one of the area that heavily occupied by the basalt, which is about 18000 hectare [2].

Strip mined process is used to produce the bauxite because it's found under the soil layer, which is 1 or 2 meter below the surface. Bauxite mining can cause adverse impacts to water, air, land, aquatics, wildlife and other biological resources if the mining is not managed or controlled properly [3, 1]. Generally, mining activities has been known to generate the environmental effect such as degradation of water quality in the affected rivers [4].

Therefore, this study was undertaken to evaluate the water quality assessment due to bauxite mining activities in Kuantan, Pahang. Water quality is a measure of the suitability of water for a particular use based on selected physical, chemical and biological characteristics. Water Quality Index (WQI) is the analysis to determine the water quality. The scientist must measure and analyse the characteristic of water such as temperature, dissolve mineral content and number of bacteria to determine the water quality [5]. According to National Water Quality Standard for Malaysia (NWQS), the water classes can be determine after calculation of Water Quality Index (WQI) (Table 1). There are six basic parameters in WQI calculations which are dissolved oxygen (DO), biochemical oxygen demand (BOD), chemical oxygen demand (COD), ammonia-nitrogen (NH3-N), pH and total suspended solid (TSS). 
Table 1. DOE water quality classification based on the WQI

\begin{tabular}{cccccc}
\hline Parameter & \multicolumn{4}{c}{ Index Range } \\
& \multicolumn{2}{c}{ Clean } & \multicolumn{2}{c}{ Slightly Polluted } & Polluted \\
\hline WQI & & $81-100$ & & $60-80$ & $0-59$ \\
& & & & Class & \\
& I & II & III & IV & V \\
WQI & $>92.7$ & $76.5-92.7$ & $51.9-76.5$ & $31.0-51.9$ & $<31.0$ \\
\hline
\end{tabular}

\section{MATERIALS AND METHODS}

\subsection{Study Area}

Kuantan district $\left(2960 \mathrm{~km}^{2}\right)$ is the state capital of Pahang. It located at latitude $3^{0} 45^{\prime} 0 " \mathrm{~N}$ and longitude $102^{0} 30^{\prime} 0$ " E. Kuantan had been identified as one of the future growth centers and a hub for trade, commerce, transportation and tourism in Malaysia according to The National Physical Plan 2005. Due to its strategic location Kuantan is considered a social, economic and commercial hub for the East Coast of Peninsular Malaysia. The big scale of bauxite mining operation had been occurred at Bukit Goh Kuantan and the ore deposits is transported to Kuantan port for processing and ready to be exported. Four sampling location had been choose within the bauxite mining areas including Bukit Goh to carry out this research. Sampling was carried out from 22 until 25 February 2017. The sampling location were Kuantan River, Pandan River, Pinang River and Riau River.

\subsection{Water Sampling}

The sampling locations had been chosen were Kuantan River (S1), Pandan River (S2), Pinang River (S3) and Riau River (S4). The coordinate of all sampling location were recorded by using Global Positioning System (GPS) devices (Fig. 1). Water sample was collected by using water sampler and stored in $500 \mathrm{ml}$ sterile polyethylene bottle. Before sampling, the polyethylene bottle was soaked overnight in 5\% nitric acid and rinsed by using distilled water for the next day. According to APHA 2005, this method is important to ensure polyethylene bottle is free from contaminants and reagent before it used for analysis. After collect the water samples, polyethylene bottle will be labelled according to sampling location. All the collected 
samples were stored in cooler box at approximately $4{ }^{\circ} \mathrm{C}$ to minimize the microbial activity in the water. Each station was being taken at three point reading and one measurement was evaluated with three replicates to get more accurate result during analysis [6].

\subsection{Water Analysis}

Water quality parameters was divided into two parts which are in-situ parameters and laboratory analysis. The parameters that were carried out as in-situ measurement are such as temperature, total dissolved solid (TDS), salinity, dissolved oxygen (DO), $\mathrm{pH}$, ammoniacal-nitrogen $\left(\mathrm{NH}_{3}-\mathrm{N}\right)$, turbidity and biochemical oxygen demand (BOD). All this parameters were measured by using YSI Professional Series Handheld Multiparameter while turbidity was measured using $\mathrm{HACH} 21000 \mathrm{Q}$ and Biochemical oxygen demand was measured using BODCheck WATERMODERN. All apparatus was calibrated before used for sampling. The parameters that being done in laboratory analysis are total suspended solid (TSS) and chemical oxygen demand (COD). Total suspended solid was determined by using Multiparameter Handheld Colorimeter (HACH DR900) while chemical oxygen demand was determined through a simple procedure. Firstly, $2 \mathrm{ml}$ of sample was added into vial that contain COD digestion reagent and was digested at $150^{\circ} \mathrm{C}$ using DRB 200 . Then, the sample was cooled in reactor for 20 minutes at $120^{\circ} \mathrm{C}$ or less. Lastly, the level of COD was measured by using DR2800 HACH.

\subsection{Water Quality Index (WQI)}

The component of WQI consists of $\mathrm{pH}$, dissolve oxygen (DO), biochemical oxygen demand (BOD), total suspended solid (TSS), chemical oxygen demand (COD) and ammoniacal nitrogen (AN). WQI was calculated by using the formula based on DOE 2008:

$\mathrm{WQI}=0.22 \mathrm{SI} \mathrm{DO}+0.19 \mathrm{SI} \mathrm{BOD}+0.16 \mathrm{SI} \mathrm{COD}+0.16 \mathrm{SI} \mathrm{SS}+0.15 \mathrm{SI} \mathrm{AN}+0.12 \mathrm{SI} \mathrm{pH}(1)$ where SI refers to sub index function for each of the given parameters and the coefficients are the weighting factors derived from the opinion poll. 

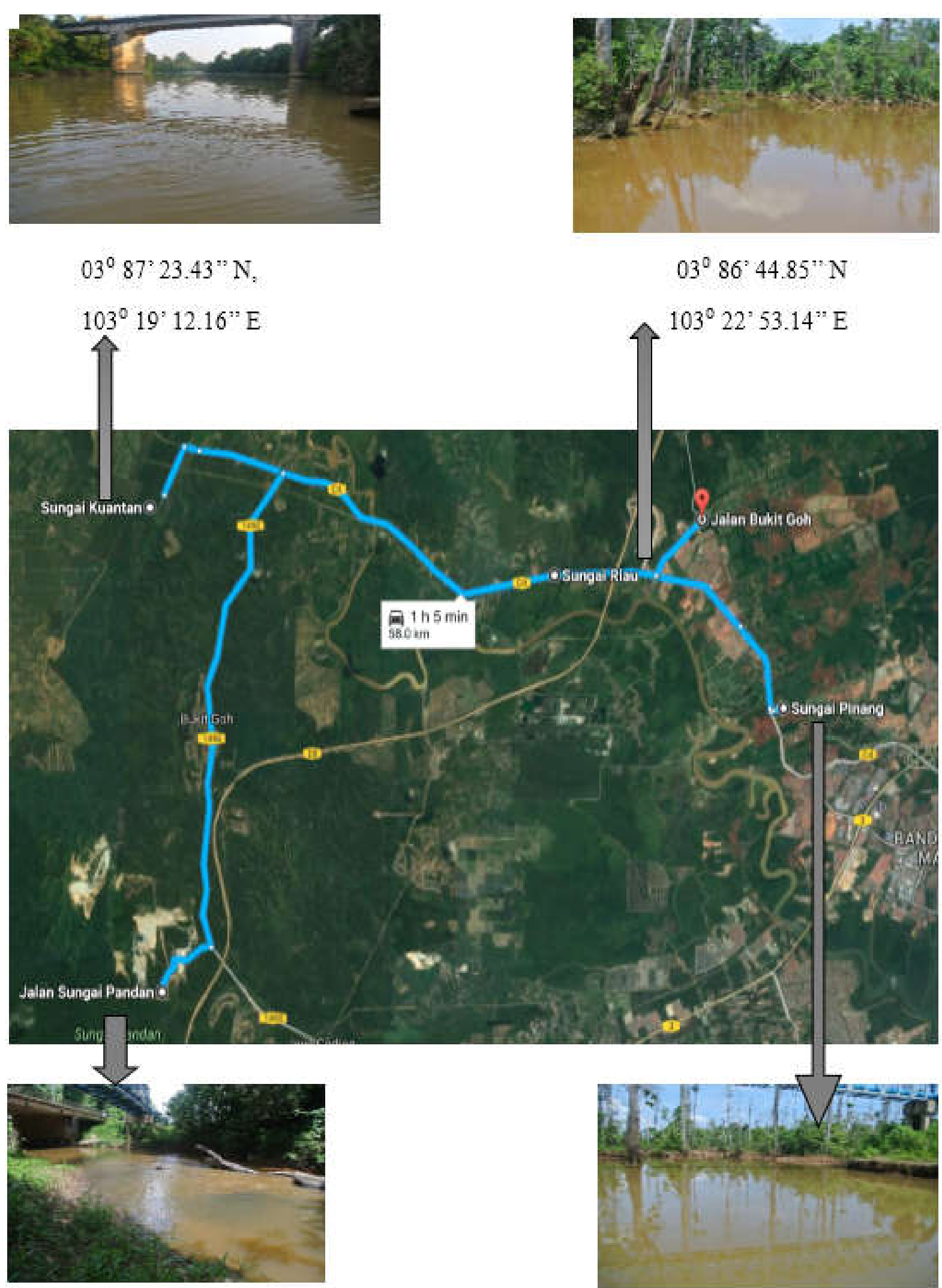


\subsection{Statistical analysis}

All the data was analyzed using one way analysis of variance (ANOVA) by using Microsoft Excel 2013. The significant differences of water quality parameters between sampling station were shown.

\section{RESULTS AND DISCUSSION}

Table 2 summarizes the mean of the physical parameters from the four sampling stations in Kuantan, Pahang. The most important ecological factor is water temperature because it controls the physiological behavior and distribution of organisms [8]. The water temperature of the selected rivers in Kuantan ranged from $27.45^{\circ} \mathrm{C}$ to $28.01^{\circ} \mathrm{C}$. According to [7], the temperature of the selected rivers at bauxite mining in Kuantan was $33.3{ }^{\circ} \mathrm{C}$ which is high from this study (Table 3). The DO levels of selected rivers varied from 6.57 to $7.05 \mathrm{mg} / \mathrm{L}$, which is within the INWQS limit (Table 3). The maximum value of DO was detected at Pinang River and the lowest value was detected at Riau River. High organic matter content and low flow of water can cause the DO value become low. High organic matter will result of the limitation primary production and increase microbial respiration by senescence of phytoplankton that leads to depletion of dissolved oxygen [9-11]. The circulation in water body was controlled by the distribution of low DO [12-13]. Higher flowing water will produce higher DO levels because of the water movement at the air-water interface [13].

The TDS of surface water ranged from 691.4 to $4524.03 \mathrm{mg} / \mathrm{L}$. The $\mathrm{pH}$ of surface water was slightly acidic and fluctuated between 6.51 and 6.90. The pH is the important factors and functions as index for pollution. The suitable $\mathrm{pH}$ for fish growth is between 7.3 and 8.4 [8]. The most suitable $\mathrm{pH}$ for diverse aquatic ecosystem range from 7 to 8 [14]. Compare to the previous study, $\mathrm{pH}$ of the rivers was 5.95 which is lower from this study (Table 4). This indicates that the river from previous study was polluted with the bauxite mining process because at that time the bauxite was actively mining. The TSS included silts and clays that cause the brownish color in the river system. The TSS in the selected rivers in Kuantan ranged from 22.93 to $67.28 \mathrm{mg} / \mathrm{L}$, which is within the INWQS limit (Table 2). The TSS was greatest at Pandan River $(67.28 \pm 5.18 \mathrm{mg} / \mathrm{L})$ and smallest at Riau River $(22.93 \pm 2.35 \mathrm{mg} / \mathrm{L})$. Rapid 
changes and extremely high TSS are stressful to fish and other aquatic organisms [15].

Turbidity is the dispersion of suspended particles. It is caused by fine sediment and organic particles [15]. The turbidity values of the selected rivers in Kuantan varied from 8.91 to 21.83 NTU, which is within the INWQS limit (Table 3). The highest turbidity values was observed at Pandan River $(21.83 \pm 1.43$ NTU) and the lowest value at Pinang River ( $8.91 \pm 1.34$ NTU). The ability of water to transmit light will decrease when the turbidity is high. High turbidity can reduced the primary productivities in the river [8]. Previous study showed that the value of turbidity is high and exceed the standard limit of INWQS compare to this study (Table 4). This indicates that selected rivers in this study is not polluted with the bauxite mining. The ammoniacal nitrogen of the selected rivers in Kuantan was fluctuated from 0.38 to $1.05 \mathrm{mg} / \mathrm{L}$. The highest value of ammoniacal nitrogen was at Kuantan River $(1.05 \pm 0.16 \mathrm{mg} / \mathrm{L})$. This indicates that the Kuantan River has influence from the bauxite mining in that area.

BOD is the amount of oxygen that required by bacteria to stabilize organic matter under aerobic conditions. Pollution that caused by microorganism through biodegradation can determined by using the concentration of BOD. The concentration of BOD in selected rivers in Kuantan ranged from 0.30 to $0.45 \mathrm{mg} / \mathrm{L}$ which is within the INWQS limit (Table 3). The highest BOD value was observed at Kuantan River $(0.45 \pm 0.02 \mathrm{mg} / \mathrm{L})$, while the other rivers has same value of BOD $(0.3 \mathrm{mg} / \mathrm{L})$. COD is requirement of oxygen to decompose organic matter and the oxidation of inorganic chemicals. The concentration of COD is varied from 28.88 to $53.22 \mathrm{mg} / \mathrm{L}$, which is exceed the INWQS limit (Table 3). This indicates that all selected rivers has higher decomposition of organic and inorganic contaminants, dissolved or suspended in water that came from the bauxite mining in that area.

Water quality index for all selected rivers was determined. The WQI of Kuantan River, Pandan River, Riau River and Pinang River were 77.141, 77.478, 81.238 and 83.164 respectively (Table 3). All these rivers were classified into class II based on Interim National Water Quality Index for Malaysia (INWQS) and required conventional treatment for water supply purposes. 
Table 2. Mean \pm SD physic-chemical parameters of the waters and water quality classification

\begin{tabular}{|c|c|c|c|c|}
\hline Parametes & $\begin{array}{c}\text { S1 } \\
\text { Kuantan } \\
\text { River }\end{array}$ & $\begin{array}{c}\text { S2 } \\
\text { Pandan River }\end{array}$ & $\begin{array}{c}\text { S3 } \\
\text { Pinang } \\
\text { River }\end{array}$ & $\begin{array}{c}\text { S4 } \\
\text { Riau River }\end{array}$ \\
\hline Temperature $\left({ }^{\circ} \mathrm{C}\right)$ & $28.01 \pm 0.54$ & $27.5 \pm 0.43$ & $27.83 \pm 0.44$ & $27.45 \pm 0.29$ \\
\hline $\begin{array}{l}\text { Total Dissolved } \\
\text { Solid (mg/L) }\end{array}$ & \multicolumn{3}{|c|}{ Solid (mg/L) } & $891.18 \pm 246.02$ \\
\hline $\begin{array}{l}\text { Dissolved Oxygen } \\
(\mathrm{mg} / \mathrm{L})\end{array}$ & $6.87 \pm 021$ & $6.63 \pm 0.25$ & $7.05 \pm 0.31$ & $6.57 \pm 0.57$ \\
\hline $\mathrm{pH}$ & $6.52 \pm 0.28$ & $6.52 \pm 0.23$ & $6.51 \pm 0.15$ & $6.90 \pm 0.55$ \\
\hline Ammoniacal & $1.05 \pm 0.16$ & $0.72 \pm 0.24$ & $0.38 \pm 0.07$ & $0.45 \pm 0.40$ \\
\hline \multicolumn{5}{|l|}{ Nitrogen (mg/L) } \\
\hline $\begin{array}{l}\text { Turbidity } \\
\text { (NTU) }\end{array}$ & $17.43 \pm 4.66$ & $21.83 \pm 1.43$ & $8.91 \pm 1.34$ & $9.22 \pm 1.31$ \\
\hline Biochemical & $0.45 \pm 0.02$ & $0.35 \pm 0.05$ & $0.30 \pm 0.02$ & $0.30 \pm 0.03$ \\
\hline \multicolumn{5}{|l|}{$\begin{array}{l}\text { Oxygen Demand } \\
\qquad(\mathrm{mg} / \mathrm{L})\end{array}$} \\
\hline \multicolumn{5}{|l|}{ Solid (mg/L) } \\
\hline Chemical Oxygen & $49.33 \pm 2.5$ & $41.44 \pm 2$ & $28.88 \pm 3.51$ & $53.22 \pm 15.10$ \\
\hline \multicolumn{5}{|l|}{ Demand (mg/L) } \\
\hline WQI & 77.14 & 77.47 & 83.16 & 81.23 \\
\hline Class & II & II & II & II \\
\hline Status & Clean & Clean & Clean & Clean \\
\hline
\end{tabular}


Table 3. Malaysia Interim National Quality Standards (INWQS)

\section{Classes}

\section{Parameters Units}

\begin{tabular}{cccccccc} 
& & I & IIA & IIB & III & IV & V \\
\hline Ammoniacal- & $\mathrm{mg} / \mathrm{L}$ & 0.1 & 0.3 & 0.3 & 0.9 & 2.7 & $>2$ \\
nitrogen & & & & & & & \\
BOD & $\mathrm{mg} / \mathrm{L}$ & 1 & 3 & 3 & 6 & 12 & $>12$ \\
$\mathrm{COD}$ & $\mathrm{mg} / \mathrm{L}$ & 10 & 25 & 25 & 50 & 100 & $>100$ \\
$\mathrm{DO}$ & $\mathrm{mg} / \mathrm{L}$ & 7 & $5-7$ & $5-7$ & $3-5$ & $<3$ & $<1$ \\
$\mathrm{pH}$ & & $6.5-8.5$ & $6.5-9.5$ & $6-9$ & $5-9$ & $5-9$ & \\
$\mathrm{TDS}$ & $\mathrm{mg} / \mathrm{L}$ & 500 & 1000 & - & - & - & - \\
$\mathrm{TSS}$ & $\mathrm{mg} / \mathrm{L}$ & 25 & 50 & 50 & 150 & 300 & $>300$ \\
Temperature & ${ }^{\circ} \mathrm{C}$ & - & Normal+2 & - & Normal +2 & - & - \\
Turbidity & $\mathrm{NTU}$ & 5 & 50 & 50 & - & - & - \\
\hline
\end{tabular}

Table 4. Mean physico-chemical parameter analysis of the rivers at Bukit Goh, Kuantan from a previous study [7]

\begin{tabular}{ccc}
\hline Parameter & Previous Study & This Study \\
\hline Temperature $\left({ }^{\circ} \mathrm{C}\right)$ & 33.3 & $27.45-28.01$ \\
Total Dissolved Solid $(\mathrm{mg} / \mathrm{L})$ & 219 & $691.4-4524.03$ \\
Dissolved Solid $(\mathrm{mg} / \mathrm{L})$ & 7.89 & $6.57-7.05$ \\
$\mathrm{pH}$ & 5.95 & $6.52-6.9$ \\
Ammoniacal Nitrogen $(\mathrm{mg} / \mathrm{L})$ & 1.53 & $0.38-1.05$ \\
Turbidity $(\mathrm{NTU})$ & 872 & $8.91-21.83$ \\
Biochemical Oxygen Demand (mg/L) & 1.2 & $0.30-0.45$ \\
Total Suspended Solid $(\mathrm{mg} / \mathrm{L})$ & 7.04 & $22.93-67.28$ \\
Chemical Oxygen Demand $(\mathrm{mg} / \mathrm{L})$ & 12 & $28.88-53.22$ \\
\hline
\end{tabular}

The significant differences of water quality parameter between sampling station showed temperature, DO, Ammonia-Nitrogen, BOD, TSS, turbidity and COD had significantly different between the rivers while $\mathrm{pH}$ and TDS shows not significantly different between the 
rivers. Correlation analysis was conducted to observe the relationship between the parameters. The results will be significantly different $(\mathrm{p}<0.05)$ if the parameters correlate with other parameters All the correlation coefficient between water quality parameter and WQI for Kuantan River, Pandan River, Pinang River and Riau River were showed in Table 5, Table 6, Table 7 and Table 8 . 
Table 5. Correlation coefficient (r) between water quality parameters and WQI at Kuantan River

\begin{tabular}{|c|c|c|c|c|c|c|c|c|c|c|}
\hline & Temperature & $\begin{array}{c}\text { TDS } \\
\mathrm{mg} / \mathrm{L}\end{array}$ & DO mg/L & pH & $\begin{array}{c}\text { Turbidity } \\
\text { NTU }\end{array}$ & $\begin{array}{c}\text { TSS } \\
\mathrm{mg} / \mathrm{L}\end{array}$ & $\begin{array}{l}\text { BOD } \\
\mathrm{mg} / \mathrm{L}\end{array}$ & $\begin{array}{l}\text { COD } \\
\mathrm{mg} / \mathrm{L}\end{array}$ & $\begin{array}{c}\mathrm{AN} \\
\mathrm{mg} / \mathrm{L}\end{array}$ & WQI \\
\hline temperature & 1 & & & & & & & & & \\
\hline TDS mg/L & -0.07427 & 1 & & & & & & & & \\
\hline $\mathrm{DO} \mathrm{mg} / \mathrm{L}$ & $0.651971 *$ & -0.25274 & 1 & & & & & & & \\
\hline $\begin{array}{c}\mathrm{pH} \\
\text { turbidity }\end{array}$ & -0.41977 & 0.317982 & $-0.5303 *$ & 1 & & & & & & \\
\hline NTU & $-0.54102 *$ & 0.348845 & $-0.57601 *$ & 0.429918 & 1 & & & & & \\
\hline $\mathrm{TSS} \mathrm{mg} / \mathrm{L}$ & -0.33332 & -0.17576 & -0.37819 & -0.23531 & 0.333365 & 1 & & & & \\
\hline BOD mg/L & $0.630537^{*}$ & $-0.49551^{*}$ & $0.604409 *$ & $-0.45998 *$ & $-0.88414 *$ & -0.21284 & 1 & & & \\
\hline $\mathrm{COD} \mathrm{mg} / \mathrm{L}$ & 0.271447 & -0.19666 & 0.421849 & $-0.54653^{*}$ & -0.24031 & $0.522972 *$ & 0.237466 & 1 & & \\
\hline $\mathrm{AN} \mathrm{mg} / \mathrm{L}$ & -0.04024 & -0.19373 & -0.34821 & $0.516939 *$ & 0.182172 & 0.019078 & 0.13104 & $-0.52574^{*}$ & 1 & \\
\hline WQI & 0.268295 & 0.275117 & 0.452298 & 0.109741 & -0.28706 & $-0.93449 *$ & 0.062042 & -0.33462 & -0.35093 & 1 \\
\hline
\end{tabular}

WQI Water Quality Index, *Indicates a significant relationship $(\mathrm{P}<0.05)$

Table 6. Correlation coefficient (r) between water quality parameters and WQI at Pandan River

\begin{tabular}{|c|c|c|c|c|c|c|c|c|c|c|}
\hline & & TDS & & & Turbidit & & BOD & COD & & \\
\hline & Temperature & $\mathrm{mg} / \mathrm{L}$ & DO mg/L & pH & NTU & TSS mg/L & $\mathrm{mg} / \mathrm{L}$ & $\mathrm{mg} / \mathrm{L}$ & AN mg/L & WQI \\
\hline temperature & 1 & & & & & & & & & \\
\hline TDS mg/L & 0.069163 & 1 & & & & & & & & \\
\hline $\mathrm{DO} \mathrm{mg} / \mathrm{L}$ & -0.17999 & 0.43253 & 1 & & & & & & & \\
\hline $\mathrm{pH}$ & 0.141679 & 0.123059 & $0.636459^{*}$ & 1 & & & & & & \\
\hline
\end{tabular}


turbidity

\begin{tabular}{ccccccccccc} 
NTU & 0.168623 & -0.41326 & $-0.4683^{*}$ & -0.07026 & 1 & & & & & \\
TSS mg/L & $0.483709^{*}$ & 0.014307 & 0.141414 & 0.246833 & -0.04892 & 1 & & & \\
BOD mg/L & -0.03095 & $-0.62582 *$ & -0.36882 & 0.279924 & $0.543729^{*}$ & -0.26869 & 1 & & \\
COD mg/L & -0.3407 & 0.381828 & $0.93441^{*}$ & 0.433029 & $-0.66499^{*}$ & 0.048546 & $-0.48495^{*}$ & 1 & 1 \\
AN mg/L & 0.003536 & $0.642811^{*}$ & $0.632231^{*}$ & 0.131381 & -0.42727 & $0.4825^{*}$ & $-0.84736^{*}$ & $0.658162^{*}$ & 1 \\
WQI & -0.17712 & -0.42146 & -0.16509 & 0.243038 & 0.307451 & $-0.65008^{*}$ & $0.829859^{*}$ & -0.25329 & $-0.84685^{*}$ & 1 \\
\hline
\end{tabular}

WQI Water Quality Index, *Indicates a significant relationship $(\mathrm{P}<0.05)$

Table 7. Correlation coefficient ( $r$ ) between water quality parameters and WQI at Pinang River

\begin{tabular}{|c|c|c|c|c|c|c|c|c|c|c|}
\hline & temperature & $\begin{array}{c}\text { TDS } \\
\mathrm{mg} / \mathrm{L}\end{array}$ & DO mg/L & $\mathbf{p H}$ & turbidity NTU & $\begin{array}{c}\text { TSS } \\
\mathrm{mg} / \mathrm{L}\end{array}$ & $\begin{array}{l}\text { BOD } \\
\mathrm{mg} / \mathrm{L}\end{array}$ & $\begin{array}{c}\text { COD } \\
\mathrm{mg} / \mathrm{L}\end{array}$ & AN mg/L & WQI \\
\hline temperature & 1 & & & & & & & & & \\
\hline TDS mg/L & $-0.48248^{*}$ & 1 & & & & & & & & \\
\hline DO mg/L & 0.07382 & 0.039109 & 1 & & & & & & & \\
\hline $\mathrm{pH}$ & -0.28912 & -0.24752 & $0.492409 *$ & 1 & & & & & & \\
\hline \multicolumn{11}{|l|}{ turbidity } \\
\hline NTU & -0.06096 & -0.19999 & $-0.55765^{*}$ & -0.13947 & 1 & & & & & \\
\hline $\mathrm{TSS} \mathrm{mg} / \mathrm{L}$ & -0.03658 & -0.39818 & $0.490157^{*}$ & 0.382048 & $-0.62239^{*}$ & 1 & & & & \\
\hline BOD mg/L & -0.18234 & 0.454894 & -0.04751 & -0.14242 & -0.3639 & 0.236731 & 1 & & & \\
\hline COD mg/L & -0.30934 & -0.07823 & -0.18674 & $0.616881 *$ & 0.195256 & -0.24951 & -0.35041 & 1 & & \\
\hline AN mg/L & 0.43326 & -0.10606 & $-0.58008^{*}$ & $-0.54169^{*}$ & 0.077934 & -0.41504 & -0.15264 & 0.107204 & 1 & \\
\hline WQI & -0.02973 & 0.20952 & $0.777514^{*}$ & 0.164019 & -0.18831 & 0.26663 & 0.117022 & $-0.53758^{*}$ & $-0.76378 *$ & 1 \\
\hline
\end{tabular}


WQI Water Quality Index, *Indicates a significant relationship $(\mathrm{P}<0.05)$

Table 8. Correlation coefficient (r) between water quality parameters and WQI at Riau River

\begin{tabular}{|c|c|c|c|c|c|c|c|c|c|c|}
\hline & Temperature & $\begin{array}{c}\text { TDS } \\
\mathrm{mg} / \mathrm{L}\end{array}$ & $\begin{array}{c}\mathrm{DO} \\
\mathrm{mg} / \mathrm{L}\end{array}$ & pH & $\begin{array}{c}\text { Turbidity } \\
\text { NTU }\end{array}$ & TSS mg/L & $\begin{array}{l}\text { BOD } \\
\mathrm{mg} / \mathrm{L}\end{array}$ & $\begin{array}{l}\text { COD } \\
\mathrm{mg} / \mathrm{L}\end{array}$ & $\mathbf{A N}$ & WQI \\
\hline temperature & 1 & & & & & & & & & \\
\hline TDS mg/L & -0.41218 & 1 & & & & & & & & \\
\hline $\mathrm{DO} \mathrm{mg} / \mathrm{L}$ & $0.565332 *$ & 0.058152 & 1 & & & & & & & \\
\hline $\begin{array}{c}\mathrm{pH} \\
\text { turbidity }\end{array}$ & 0.04563 & -0.16429 & 0.04057 & 1 & & & & & & \\
\hline NTU & -0.3606 & $0.60128 *$ & 0.087938 & 0.108909 & 1 & & & & & \\
\hline TSS mg/L & $-0.82048^{*}$ & $0.500589^{*}$ & $-0.5584^{*}$ & -0.27925 & $0.539009^{*}$ & 1 & & & & \\
\hline BOD mg/L & 0.24724 & -0.43665 & 0.041386 & $0.623786^{*}$ & 0.175844 & -0.21845 & 1 & & & \\
\hline COD mg/L & -0.21284 & 0.122746 & 0.024052 & $-0.81346^{*}$ & -0.05574 & 0.309144 & $-0.77035^{*}$ & 1 & & \\
\hline AN & $0.532319 *$ & -0.01509 & 0.326083 & $0.701429 *$ & 0.191487 & $-0.55483^{*}$ & 0.454876 & $-0.7025^{*}$ & 1 & \\
\hline WQI & 0.09868 & -0.11107 & 0.444778 & -0.43891 & -0.35774 & -0.1628 & -0.1409 & 0.364964 & $-0.57244 *$ & 1 \\
\hline
\end{tabular}

\footnotetext{
WQI Water Quality Index, ${ }^{*}$ Indicates a significant relationship $(\mathrm{P}<0.05)$
} 


\section{CONCLUSION}

Physico-chemical analysis showed that Kuantan River, Pandan River, Pinang River and Riau River was a clean rivers (Class I and II) except ammoniacal-nitrogen, COD, TSS and TDS that exceed the standard limit of Class II in INWQS as a results of bauxite mining activities in Kuantan Pahang. Water Quality Index of Kuantan River, Pandan River, Riau River and Pinang River were 77.141, 77.478, 81.238 and 83.164 respectively. All these rivers were classified into class II based on Interim National Water Quality Index for Malaysia (INWQS) and required conventional treatment for water supply purposes. Proper management and planning is required to prevent the further damage of river ecosystem from bauxite mining. It is well-known that the recovery of the river from the mining activities effects may take several years depending on the environmental dynamics.

\section{ACKNOWLEDGEMENTS}

The authors would like to thank Universiti Sultan Zainal Abidin and Ministry of Higher Education for support the FRGS grant (RR212).

\section{REFERENCES}

[1] Abdullah N H, Mohamed N, Sulaiman L H, Zakaria T A, Rahim D A. Potential health impacts of bauxite mining in Kuantan. Malaysian Journal of Medical Sciences, 2016, 23(3):1-8

[2] Paramananthan S. Soils of Malaysia: Their characteristics and identification, Volume 1. Kuala Lumpur: Academy of Sciences Malaysia, 2000

[3] Arvind K. Dimensions of environmental threats. New Delhi: Daya Publishing House, 2003

[4] Lamare R E, Singh O P. Degradation in water quality due to limestone mining in East Jaintia Hills, Meghalaya, India. International Research Journal of Environment Sciences, 2014, 3(5):13-20

[5] Islam M S, Ismail B S, Barzani G M, Sahibin A R, EKhwan T M. Hydrological assessment and water quality characteristics of Chini Lake, Pahang, Malaysia. American-Eurasian Journal. Agriculture and Environment Sciences, 2012, 12(6):737-749 
[6] Water Environmental Federation and American Public Health Association. Standard methods for the examination of water and wastewater. Washington DC: American Public Health Association, 2005

[7] Kusin F M, Rahman M S, Madzin Z, Jusop S, Mohamat-Yusuff F, Ariffin M. The occurrence and potential ecological risk assessment of bauxite mine-impacted water and sediments in Kuantan, Pahang, Malaysia. Environmental Science and Pollution Research, 2017, 24(2):1306-1321

[8] Krishnamoorthi A, Senthil E P, Selvakumar S. Investigation of water quality parameters for aquaculture-A case study of Veeranam Lake in Cuddalore District, Tamilnadu. International Journal of Current Research, 2011, 3(3):13-17

[9] Mandal S, Ray S, Debnath M, Ghosh P B, Roy M, Ray S. Dynamic modelling of dissolved oxygen in the creeks of Sagar Island, Hooghly Matlah estuarine system, West Bengal, India. Applied Mathematical Modelling, 2012, 36(12):5952-5963

[10] Prasanna M B, Ranjan P C. Physico chemical properties of water collected from Dhamra estuary. International Journal of Environmental Sciences, 2010, 1(3):334-343

[11] Parr L B, Mason C F. Causes of low oxygen in a lowland, regulated eutrophic river in Eastern England. Science of the Total Environment, 2004, 321(1):273-286

[12] Yin K, Lin Z, Ke Z. Temporal and spatial distribution of dissolved oxygen in the Pearl River Estuary and adjacent coastal waters. Continental Shelf Research, 2004, 24(16):1935-1948

[13] Radwan M, Willems P, El-Sadek A, Berlamont J. Modelling of dissolved oxygen and biochemical oxygen demand in river water using a detailed and a simplified model. International Journal of River Basin Management, 2003, 1(2):97-103

[14] Maun C, Moulton P. Optimal water quality standards for aquatic ecosystems. Washington: Nisqually River Education Council and Nisqually River Council, 1991

[15] Yen T P, Rohasliney H. Status of water quality subject to sand mining in the Kelantan River, Kelantan. Tropical Life Sciences Research, 2013, 24(1):19-34 


\section{How to cite this article:}

Yaakub N, Raoff MNA, Haris MN, Halim AAA, Kamarudin MKA.Water quality assessment of the rivers in bauxite mining area at kuantan pahang. J. Fundam. Appl. Sci., 2017, 9(2S), 761-776. 